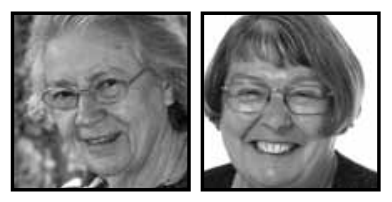

\title{
Aspects of Museum Education in School
}

\author{
Susan Humphries \& Susan Rowe
}

\begin{abstract}
A group of teachers working with children, parents, and friends of the school have explored ways to develop environmental, artistic, social, and cultural awareness through events and workshops based on museum education. They saw power in the notion of collections of things that would impact on children's formal and informal learning. This article describes aspects of museum education in school.
\end{abstract}

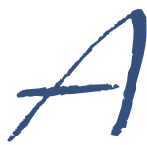

Imost every child has a sense of the value of personal collections. These can generate a surge of memories about a holiday by the sea, support an interest in fossils, or extend the designs that children build with their modular kits. They can also be amongst their first attempts to categorize various countries from a hoard of overseas cards and stamps. No matter what the subject of the collections, each item tells a story and carries a personal history to the collector. It is one way for an individual to express values and current interests in much the same way as adults do when furnishing a home for the first time. Notions such as these had a bearing on teachers planning work for children that is aimed at deeper levels of participation. We thought that by exploring the children's treasures and the heritage of home, community, and school we could make collections of aesthetic and scientific importance. We could also make special links to the outdoor environment so that the spaces there would display a variety of beautiful rocks among growing flowers and trees in unique collections. These permanent exhibitions were sown, planted, and built up by the community over a period of thirty years and fulfilled a particular need, providing evidence for the children to study and get the taste for enjoying life in the natural world. Our collections advanced the prescribed national curriculum as well as providing opportunities for informal learning. Overall the plan was to bring together the indoors 
and the outdoors in an integrated way. Adults and children would touch everything, socialize with one another, and connect with the features in the landscaped setting that would resemble a country park. ' We saw all of this work as an application of the collections principle to daily life.

As discussions around museum style experiences went on, the teachers felt that one way to realize this on a regular basis would be through borrowing objects in a systematic way. Exhibitions could be put together for a short life of one or two days, the collections would flow from the thematic work that shaped our curriculum teaching and would be another axis for the exploration of the subject matter. Acquisitions would be honoured by their treatment as treasures: each shown in its own space positioned among related items and presented on textiles and other surfaces so that the artefacts were in a scene that invited people in to view. We would involve our school community in resourcing, setting up, and curating the different exhibitions and parents and carers would catch the children's enthusiasm for the projects when talking about them at home.

The collections and displays were as far as possible to hold true to the ideals of multisensory stimulation and follow some best practice in the museum service of conscientious provenance of objects meant to deliver a feast for the eyes in a contextual framework. Many exhibitions are simple and short lived: one was based on food from the sea.

\section{Food From the Sea}

A parent who managed a wet fish shop helped us to set this up by providing a generous donation of different species of fish and shell fish. These were laid out on a groundsheet covered with sand and shells. Each class of children watched as fish were washed, filleted, de-scaled, and trimmed and other parents dipped the fillets in flour and egg before frying them. The children ate their taster as they sat around the marine display and the fishmonger talked about the environmental goals of keeping the seas and beaches clean and about fish quotas. He also described the negative impact of industrial chemicals on our rivers and seas and the fate of creatures caught in oil-spill disasters. All the children in school visited the museum throughout the day and the supplies of fish were replenished from an insulated container. This sort of teaching echoes conventional environmental education and it also helps children and adults to become more aware of the interconnected nature of the planet. ${ }^{2}$ Eating some of your learning makes it a part of you and the smell of the sea and of fish cooking makes up for the exhibition being only moderate in scale. 


\section{Geology Trail}

Our school grounds have been transformed as a result of the teachers' determination to teach authentically from firsthand knowledge. ${ }^{3}$ Geology, geography, and botany are experienced through the quality of the collections that form a permanent resource. Large rock specimens have been introduced from different parts of the UK to make the study of geology an everyday interest. The children play on and around memorable landmarks that make powerful aesthetic contributions to the school setting. In every case the introduction of the groups of rock was managed so that they become references to heritage and early history. One group is the massive rectangles of Yorkshire limestone that were set in a circle so that they had parallels with the many ancient stone circles built to honour the sun and with the purpose of measuring time. Two of the blocks carry a stone crossbeam similar to those of the Stonehenge monument in Wiltshire: this tri-form orientates the circle for sunrise and sunset at the spring solstice. The children call this landmark "Coombeshenge." Parents used machines to dig holes to anchor the stones that have one third of their mass and length in the ground. This is ancient technology and is our attempt to respect the original methods as we put the work before the children. All through the day groups of children watched the work in progress and they observed the changes to the landscape; later they all helped to restore the ground after the installation was complete by spreading large quantities of bark chippings around the base of the stone circle.

Gritstone from Derbyshire was gifted by workers in a quarry where there was an adjacent dolmen (Neolithic burial chamber). We re-created an ancient chamber using similar-sized blocks and there is a strong resemblance to the original. Our version has the addition of cut and polished undersides so that the children can see the inner colours of the stone. When cut and polished the stone indicates its commercial value for the construction of fireplaces, floors, and memorials. Four or five children can sit in the covered area and there is space for twenty children to sit on the upper surface.

Two caves, one of pink granite from Aberdeen and another of red sandstone from Gretna in Dumfries and Galloway, suggest the time when sheltering beneath the rocks limited access to predators and gave an easy-to-defend base for those who needed sanctuary. Each set of stones exists in the school surroundings as an example of the topography of the region from which the stones were accessed. The children go inside the caves to experience the accentuated sound, the gloom, and the hollow atmosphere. 


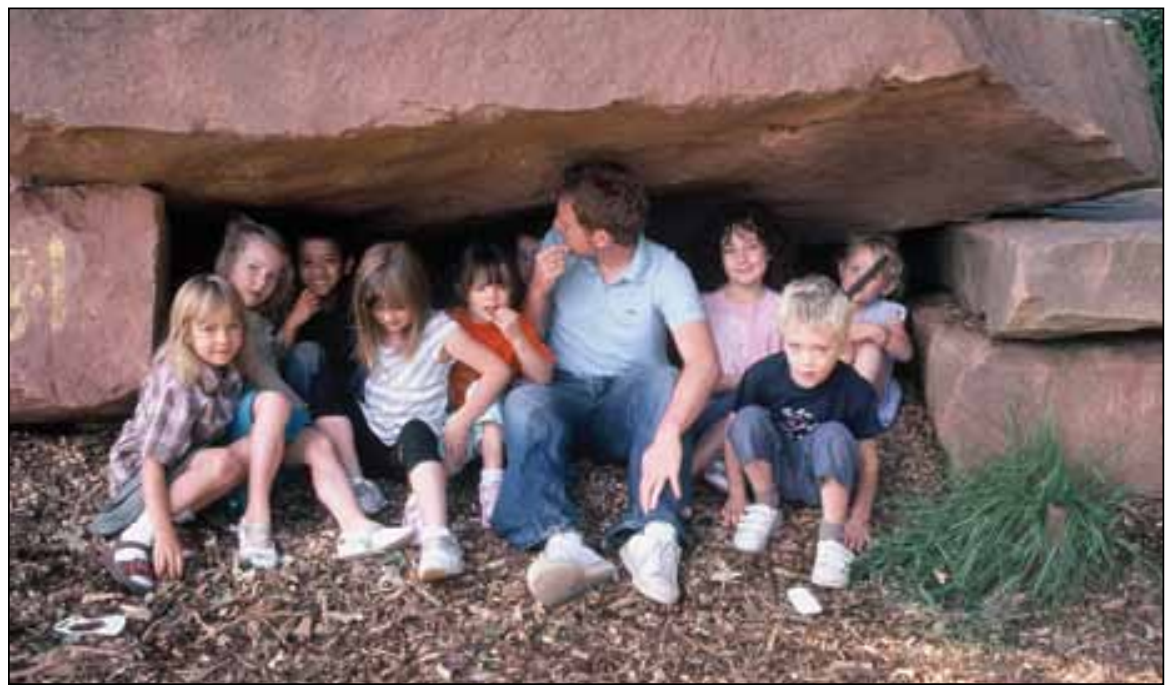

Fig. 1: Geology trail - sandstone cave

They stand on the summit to call for attention, view their surroundings, or emphasize their climbing power because this is in keeping with the character of these places.

Twenty Cotswold rocks aligned to a pathway give an alternative route for children wanting to walk tall next to their adult parents and carers. These are stones of great antiquity and fossil rich. Four Faringdon sponge rocks formed near Oxford when tropical conditions prevailed in the area are simply millions and millions of dead sponges and sea creatures that have been coalesced into stone. The boulders give detail of an early climate change in Europe and the comparison between these stones and other types helps to suggest the immense span of time before human life became a feature on earth.

Welsh slate, Cornish granite, Purbeck limestone, millstones, conglomerate rocks from Somerset, Sarsen, stones and Lake District sandstone have been set up to form part of our school geology trail. Each group of rocks has its own appeal: together they are part of the school's resources as geological samples from mainland Britain. One long-term objective was that the collection would function as a showcase for the earth sciences and a fascinating study of our planet's history. ${ }^{4}$ Most are easy and safe climbing challenges for the children and enticements to understand more about geology and a variety of terrains. Our trail has taken eighteen years to evolve and is used for both formal teaching and informal learning. 


\section{Native Wildflowers}

Early in our school's history we declared our intention to educate children about the environment and the need to be stewards of the planet. The pathways that lead children around the geology trail feature small wild patches that were typical across the ancient countryside for more than a thousand years. These wild spaces provide a statement about the balance that can exist between the needs of people and the needs of nature. Wildflowers used to be harvested for medicines and as dyes and once they are established they can become an enduring feature perpetuating themselves year by year. They are responsible for insect diversity and the flowers are also a constant source of pleasure for the children. The more diversified the flora, the more abundant the species of fauna. Birds need insects and as the flora gradually increases, a complex web of life evolves in these areas that become sanctuaries and feeding stations. Every year the wildflowers are renewed in some way. Sometimes this is through seed introduction when a small patch of prepared ground is sown by the children and protected with stakes and a net. At other times plants such as cowslips are introduced as plugs and merged into grassland.

Collecting evidence about plants is a great stimulus to learning: it can engage all the senses and be an artistic activity. The children gather tiny pieces of the flowers on cards that have a strip of double-sided sticky tape down the centre. These colour cards are packed with minute bits of evidence about the quality of the landscape and what can be found in it on any particular day.

Many artistic ideas are expressed through art ephemera..$^{5}$ In order not to detract from the environmental ethic of care for native plants, we use seeds, fallen leaves, fruit, pebbles, feathers, and sticks to create artwork out of doors. The children work alone or in groups to set arrangements of these found objects from the school grounds. The selections are naturally short-lived and we capture them in photographs for the future. Sticks and pebbles are always returned to where they were found at the end of the activity. We avoid picking the wildflowers for these displays. Each year the children plant narcissus bulbs so that they can pick the flowers as gifts for their mothers in the following spring: some of these blooms are also incorporated into the children's ephemeral art. The teachers raise questions with the children about what can be picked and what should remain untouched in the wild. It is generally determined by who did the planting and why. The act of personal involvement in the planting and in the gathering and arranging at blossom time is a way of exploring creativity and the benefits of the garden. It also acknowledges the issues of responsibility for planting and harvesting that allows for living material to be taken from its source. 
Wild plants have many stories to tell. Some offered remedies and were used to staunch bleeding or applied as poultices. Others were used to flavour food or beer and the flowers and berries of some were gathered to make cordials. Wild fennel and garlic were roasted and eaten and the nettle was an alternative to flax and an edible green vegetable. There are a wide variety of stems and leaves that can be harvested for salads, and in hard times our ancestors augmented their diet from the herbs and flowers of the untended land.

\section{Arboretum}

When we started planting our grounds it seemed practical to enhance the children's perception of trees and bushes by planting an arboretum. Forest trails are the best-known family walks and we created these trails over the years with help from the children and the community. The centrepiece of the grounds is the sports area: a football pitch that becomes an athletics track and is used for all team games and physical education. The southern periphery of this area is a low bank made much more striking by the addition of truckloads of soil. This surplus was available through a local road-widening scheme and a mixture of subsoil and loamy earth raised the level of the bank considerably. Forest trees were planted in this by the children and those trees that lived spread their roots to secure the bank and limit access to the perimeter pathway. The long wide bank on the south side of the school field tapers to a narrower bank on the west side. There is a change of level in the school grounds from the southern boundary to the northern boundary although the sports pitch was graded to make a level plain in the centre. The sloping nature of the site makes it much more interesting to plant and at the steepest part where the land falls away from the sports pitch we concentrated on further planting that has resulted in a small woodland.

Every type of indigenous tree and bush is represented in strings of planting and there are also groups of fruit trees all around the school. The fruits are gathered by the children as part of the lessons on healthy eating, biodiversity, seed-to-seed cycles, self-sufficiency, pollination, and symbiotic relationships. Leaves and seeds from the various trees are used for ephemeral art. The paths with wide sets of steps and informal seating make fun teaching spaces and a windswept bleak site has become a friendly setting for teaching. Simultaneously, the sports ground has been transformed because the planted edges and banks make the open area appear more prominent like a stage. Trees flanking the margins cut the wind speed and give shade, texture, and colour. In some spaces, teachers, parents, and children have tied the trees together. A group of six ash trees have been twisted into each other and secured with 
ties: as these grow they form a highly original pattern with main-stem growth forming entryways that invite the children to go through or stop to feel the bark. Willow has been similarly treated so that it loops into a series of connecting arches. There are learning and playing opportunities, a choice of places to build dens and gain an experience of designing shelters. The woodland atmosphere has been produced slowly with imported bark chip and sawdust helping the previously almost waterlogged ground. The ambition and determination of teachers, children, and parents to make the whole planting a caring statement has led a step at a time to a fine collection of trees.

The route through the woods is waymarked by bark chipping paths and in the autumn rose hips, haws, elderberries, sloes, apples, and plums fruit along them. Birds have moved in for the insect life that trees harbour and bluebells are well established. This is a living collection for children transformed into a scene of beauty with blossoms, changing leaf colour, and the harvest of berries and fruit to look forward to.

Frost, snow, and ice play their part and sometimes we light candles on the pathways and invite the children and their carers to make candlelit walks during the winter. The arboretum is an aesthetic attraction: it supports wildlife and gives a sense of adventure to the regular explorations we make in the gardens. The wildflowers, the geology trail, and the arboretum are permanently on display: importantly they give children choices about where to play and what to look for and there is an element of pride in being able to describe the best views, the expeditions to the rocks, apple picking, or den building: these sorts of things have a personal meaning.

\section{Spider Museum}

In the autumn the presence of orb-web spiders is evident through their webs that are outlined by the heavy dew and frost. These hang in the spider's silk, revealing the geometry of the web and attesting to the strength of every strand. Sometimes we spray the web with car paint (making sure in advance that the spider is out in a resting place). We put a card misted with glue behind the web, cut the silk on the external framework, and capture the web to study. The spider is able to weave a replacement web in about two hours. Webs tend to be asymmetrical with the hub of the web nearer to the top: the spokes of the web are built in separate arcs and not in a continuous spiral as may be generally assumed. Most gardens have several types of orb-web spiders and also a range of other spiders to be found on trees and bushes as well as inside our houses, sheds, and on our lawns. 
Learning to love the beauty in your own back garden is about teaching for transfer. Perception grows little by little and the lessons in nature such as the spider webs are scientific, mathematical, and spiritual.

The teachers thought we should have a one-day museum based on spiders. This would be a timely reminder to everyone of the value of spiders to wildlife in general and we could also acknowledge references to the spider in our literature as in Charlotte's Web, the tale of Robert the Bruce, Brer Anancy, Miss Muffet, and the like. Our local Chinese take-away restaurant donated boxes with transparent lids so that each teacher and child could take one home on a Friday. Explanations were given to the children about how to search for and humanely capture the spiders and notes went home a week before the collection describing techniques to the parents and details about care of the creatures. We asked for short written descriptions about the search and capture and emphasized the importance of the spiders' welfare and the fact that they would be exhibited according to the details supplied. During the weekend we constructed and fixed a floor-to-ceiling spider web in the centre of the school hall using string. We also set up an exhibition of pictures, books, and a film on loop as a guide to a spider's life as well as a number of display tables covered in black cloth. On Monday most of the children came to school with a spider referenced to its place of capture and with written information and sometimes photographs and children's drawings. The children were helped to place their spiders in the relevant part of the museum. Any children without a spider were helped to collect one from around the school site, using the tool shed, cleaners' cupboard, hedges, and fences. A local expert talked to all the classes about the spiders on display and also brought his own collection of living and dead creatures. ${ }^{6}$ At the end of the day, the children collected their spiders to take home and release safely back into the environment in which they had been found.

\section{Chair Museum}

Some themes have been so memorable that we repeat them every four years or so. An installation exploring the theme of chairs depended a lot on the contributions loaned by parents and grandparents. The gathering of old, unusual, or muchloved furniture offers great contrasts within a single category of items. In the last collection we had five high chairs, seven rocking chairs, a number of handcrafted chairs, and a comprehensive set of designer chairs. One section of the museum showed wheelchairs including a historic bath chair with a sepia tint photograph of a greatgreat grandfather using it. There were nursing chairs and a commode and in another section there were folding chairs and portable seats including milking and fishing 
stools. The exhibits tell the story of individual family preferences in style and demonstrate modern and old versions of the same article. The commode chair brought giggles but gave us the opportunity to talk about growing old, changing needs, and incapacity. The answer to need is a design that provides a solution. A chair is primarily a perch to accommodate weight and a version of a resting place. Office chairs, bar stools, children's chairs, and other modern versions of chairs are easy to come by but it is important that the modern exhibits are viewed alongside older items. The key questions around design, function, materials, and relationship to comfort or fashion become easier if half the objects have a longer history.

The character of every display is defined by contributions from parents, teachers, and friends. It is vital to ensure that several curators are on hand throughout the museum's life in order to care for the exhibits and to give the children further information about them. Often parents will send their contributions with written descriptions and explanations and the curators will help the younger children to read these.

Employing a variety of layouts for the diverse collections is part of the purpose for doing this sort of work. It changes the atmosphere of the school hall or the classroom when the spaces are filled with non-school objects and it represents a bridge between home and school. Everyday objects become more interesting and can be seen for what they are: cultural expressions and items of taste, choice, or sentiment. A part of the work is about developing the discerning eye, separating function from ornamentation, making comparisons, and discovering personal preferences. All this is practice for identifying relationships between things and deepening our sense of design.

One log stump and one round stone represent the earliest seating and these are set together on a rush mat. The children are accustomed to these types of seating because they are a part of the school site and part of the playground arrangement. In the display they are a contrast to manufactured seating and can prompt us to reflect on first solutions followed by adaptation and invention. The tradition of chair making in the woods meant that the timber for this craft could be selected and cut on site. During the life of two chair museums we have identified suitable trees in the school garden, cut them down, and a craftsman parent has demonstrated the old skills of turning wood on a pole lathe and green wood joinery. Ash was used to make the first of our school chairs. The children still sit in this every day because it was made for them as part of their furniture. In a different chair museum, the same parent also made a storyteller's seat using willow and hazel. This is kept in one of our 
tree houses but the timber was cut from the school site, and from start to finish the children visited the craftsman formally and informally while the different processes were followed. Essentially this connection between the woodland and the furniture is visual and the coppice re-growth is slow to fill the gap. Years of growth followed by a sudden empty space are elements of loss in the natural world and part of the production cost. Some trees flourish with this type of forestry, springing up later as a multi-stemmed tree and illustrating sustainable methods of production.

On another occasion we installed items of wooden furniture in relevant trees in the school grounds: a chair made of beech was winched into the fork of a young beech tree, a walnut bedhead was attached to the branches of one of our walnut trees, a folding table made of oak was suspended in an oak tree, and thirty wooden spoons were hung in an aspen. Eight different items decorated the willows showing the breadth of use of this type of wood. A pine rocking chair and a pine plank were propped against a Scots pine and spades, forks, and other garden tools with ash handles were hooked up to the branches of the ash trees. The children were entertained and informally educated as they walked the pathways in search of more exhibits.

When we call for loans the teachers and children try to make clear demarcations of function in order to place the different objects within broad bounds. We use rugs, blankets, and carpets on the floor to define the areas for each agreed-upon category. In practical terms this means chairs to test by sitting in them, the guarantee of touch and feel where seats are leather or velvet, chairs that move (rocking chairs, chairs with rollers or reclining features), chairs that are for the eyes only because of their long history or sentimental value. The idea of safeguarding for the future applies to fine arts, the natural world, and to personal history and is a piece of the whole teaching through museum-style projects.

The children come to the museums in their class groups and they make at least two visits. The first of these will be to enjoy the museum as a whole, to walk around, and talk about the exhibits and to touch and feel when appropriate. The second visit will invite more detailed examination and often the children will come with clipboards and paper to make notes or to draw from life.

\section{Textiles Museum}

The museums are semi-formal, ensuring things to touch and often relying on craftspeople to demonstrate the use of specialized tools. In their time many of these tools were innovations and the children need to appreciate the effectiveness 
and elegance of hand tools and simple machines that rely mainly on human energy. Textile manufacture operated for thousands of years on this basis and one of the joys for the children is to see clothes and things of quality produced by people they know who are operating simple devices such as knitting needles, crochet hooks, and rug fastening hooks.

A two-day museum is regularly connected to the shearing of the four school sheep. Two grandparents and a retired teacher work on a loom using threads spun by the children and adults from the sheep fleeces. The children use carding combs to clean and untangle the raw wool and to make sure that the fibres are consistently lying in the same direction. A second process involving spinning is displayed by two friends from the local craft guild who work on spinning wheels to make dependable lengths for the loom.

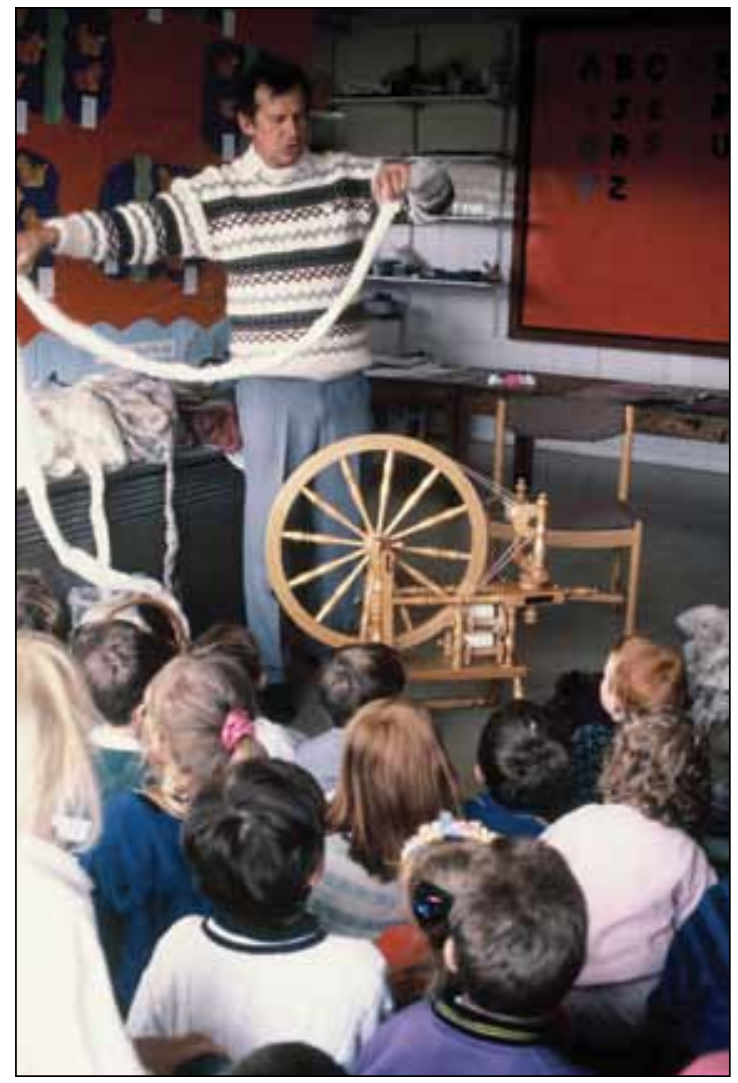

Fig. 2: Textiles museum — spinning 
Children and helpers use spindles to wind threads for the loom but this process is not easy as it is hard to get thread of a regular density. By the close of the museum on the second day a small blanket is manufactured from start to finish. Artefacts in the exhibition include patchwork quilts, crocheted shawls, hand-woven blankets, hooked rag rugs, knitted toys, baby clothes, and sweaters. There are appliquéd patterns and pictures and examples of tapestries and felt work. Many children make felt from the surplus fleece and produce dyes from plants in the garden to colour the fabrics. One parent worked her early twentieth century hand-operated sewing machine for the entire two-day period and its lack of sophistication gave the children scope to recognize the techniques mastered with this invention. As a contrast to the old machine, a computerized version was being used on the opposite table by a parent who did garment alterations as part of her job. The support from the local craft guild, parents, grandparents, carers, and their friends is needed to make these projects happen: they become working exhibitions such that the children can experience textile production from the past with its demanding routines and its rewarding social implications. Getting to know the substance itself-wool in all its adaptability-is also revealing: the smell and texture of the wool, the clatter of the loom, the sounds of sewing machines, knitting needles, feeling the nap on the felt and on the surface of a blanket, and discovering the smell of heated wool and its blending characteristics as it is turned into felt.

Whenever possible we talk about renewable energy sources. Obviously work of the type described is about promoting craft skills so these might become leisure activities in the children's future. This is all about sustainability because it suggests that to make something oneself can help individuals to be less dependent on commercial products, and it keeps alive our interest in the old tasks and crafts.

One table in the exhibition holds a button box, button-hole scissors, threaded needles standing in a pin cushion, an old needlework box, hooks and eyes, press studs mounted on tape, a tapestry frame holding a part-worked tapestry, and two samplers from 1820 and 1860 made by children in those times. These small details reflect old skills and it is the intrinsic heritage value of an item that is more important than its monetary value. Each time, the museums are different because the people engaged in them vary. The specimens that are loaned have a story and all are linked in some way to the children in school. Because of this the collections help us to be conscious of what we have in our own locality and in our own community. 


\section{Transport}

A focus on transport can be so extensive that it can become hard to manage. We prefer to examine one or two aspects of transport in depth. On one occasion we based our work on horsepower: this was not a static display but rather an example of learning in action. Horsepower was formerly an imperial unit of power equal to about 750 watts and was for many years in common use as a measurement of engine power. We decided to approach the idea of transport through the daily visits of the postman because the children had some active knowledge of the work of the postman on his rounds at home and at school. We arranged for all the classes of children to meet the postman in his van at the front of the school and to collect the school post. He gave them an overview of his work, bringing a delivery bicycle on two mornings and a post office van on two other days. He also explained that the delivery of letters was originally financed by the receiver of a letter prior to the introduction of the Penny Post in 1837 and that postal deliveries were made on horseback or mail coach.

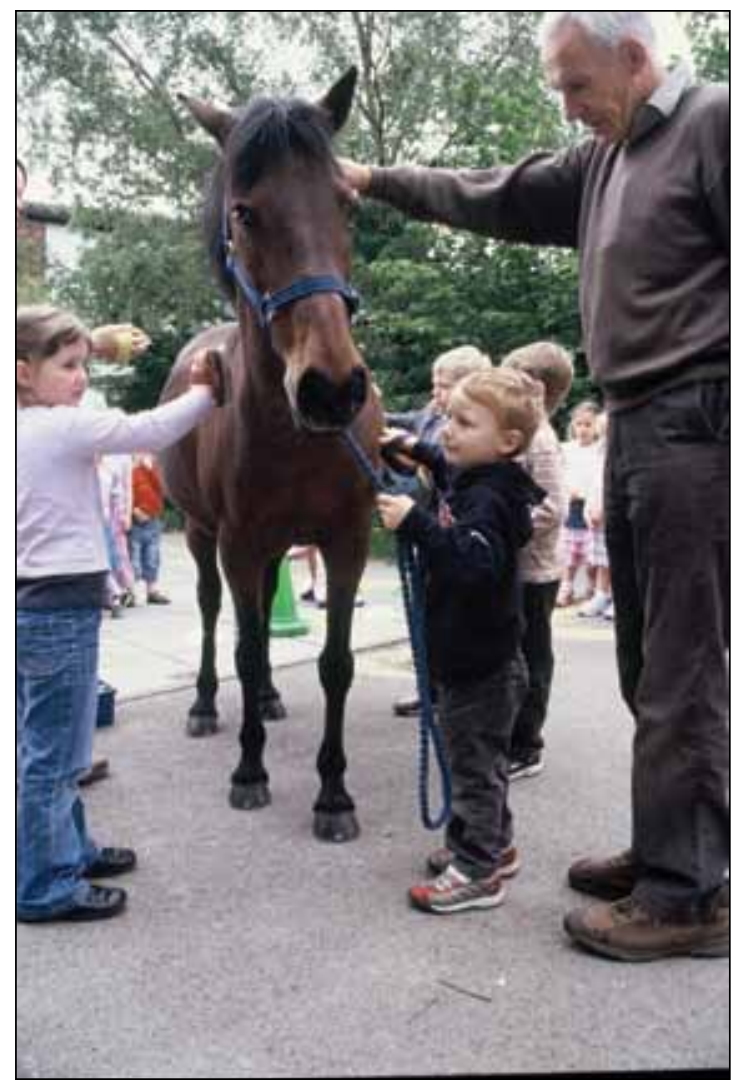

Fig. 3: Transport museum — horsepower 
In the following week, special postal deliveries were made by a "postman" on horseback who carried a letter for every child in school: this illustrated our former dependence on the horse at a time when it was fundamental to the delivery of most goods and services.

Each child paid a penny to the postman on receipt of the letters. Following this, all the children were pulled around the school field in a pony and trap to evoke the old means of transport.

We extended this project to make a display of vintage cars, bicycles, motorbikes, and tractors sourced from our local community, and this helped us to trace the development of transport from a dependence on the horse to a dependence on machines. All the motor exhibits were ridden and driven across the playing field and up and down the school drive by members of our parent group. The engines idled with open views to the working parts and the journeys made in front of the children were memorable because the vehicles were all so striking. The machines were curated by their owners who revved the engines, sounded the horns, and gave personal anecdotes about the history of the vehicles. The help of many parents and friends of the school allows these cultural adventures to happen every term.

\section{Art}

We try to bring the exhibitions to life through art. All the arts enable us to have a greater understanding of life and can give us a glimpse into the past as well as into a possible future. One of our recurring activities with the children and adults is pavement art where we are all participants in an instant art gallery. We use chalk and charcoal to draw on the paved surfaces outside. The pictures drawn blend into each other and the gallery can be visited during and after school with parents and carers. Pictures in these media have a very short life and are washed away by the first shower of rain or trample of footsteps. The exhibition depends on collaboration and cooperation as well as on spontaneity and is often recorded photographically for later discussion.

Two or three times during a year we draw exhibitions of pictures together. The core of these collections are displays of sunflower pictures by artists who have been inspired by these flowers and scenes of gift-giving displayed in January. The tenet of these art galleries is in revealing more details about what we already know. In the case of the sunflower images they have a bearing on the mass planting of sunflower seeds by the children in the early summer. 


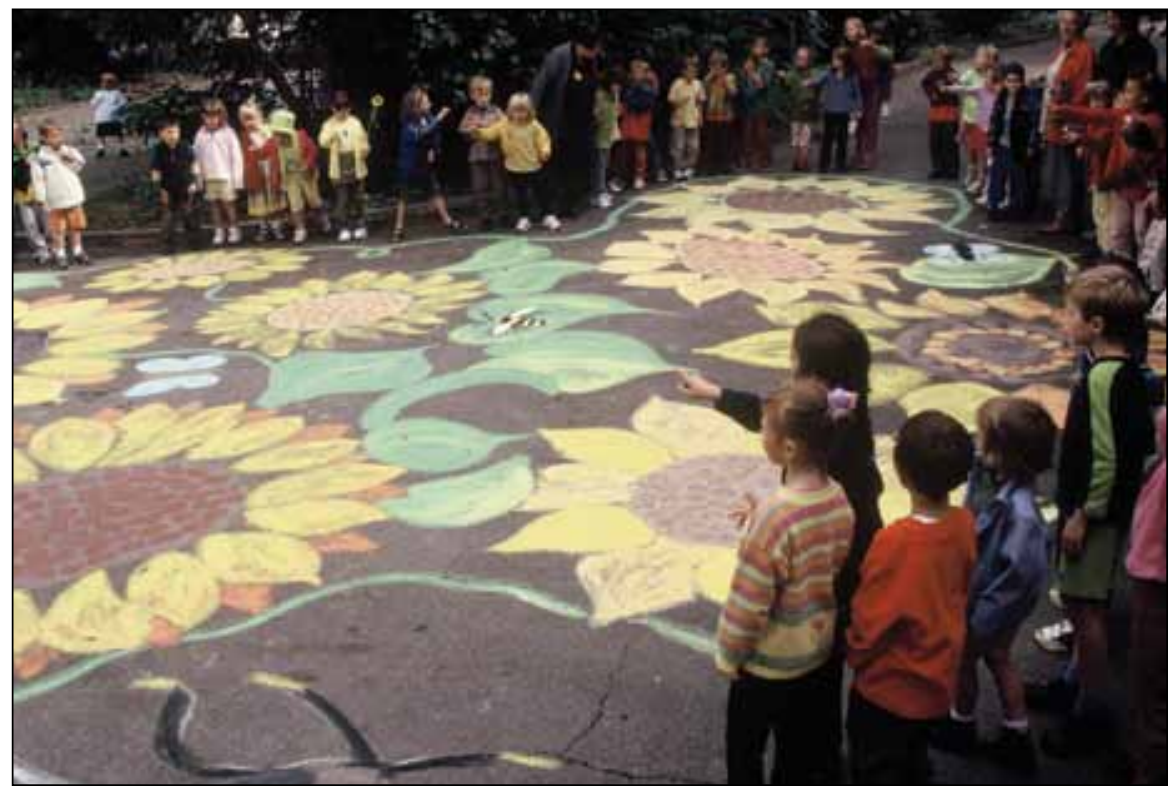

Fig. 4: Sunflower art

The exhibition of pictures synchronizes with the blooming of the sunflowers in September. Art gallery reproductions by Monet, Vincent van Gogh, David Hockney, Van Dyck, Georgia O'Keefe, Isaac Fanous, and others are the inspirations.

\section{Conclusion}

Our intention in offering regular exhibitions is that the children are encouraged to want this kind of exploration for the rest of their lives. The learning style is about independent fact finding, prospecting new tastes, and making the most of what a community might offer. It is also about reciprocity in that giving time, talent, and interest to a project has a big impact on the children who will hopefully develop these lifelong dispositions.

If parents never go to museums, art galleries, great gardens, or fine collections how do their children get their bearings among such things? One purpose of the collections/museum approach is to bridge the divide between different kinds of cultural appreciation because the divide is artificial. We need to help children and 
the community to extend their appreciation so that they can view the world anew, making fresh interpretations when looking at images and artefacts, handling collections and craftwork. This stretches aesthetic awareness and presents a bigger scene of life with different challenges. Experiences are what shape us: our disposition and learning potential are hooked into the stimuli we receive. The brain's expansion is consequent upon the networks of connections between brain cells. These cells are set to respond to sensory stimulation and the more cells are called upon to function the more they are extended. The best conditions for all children are those that are stimulating, multi-sensory, and full of positive feeling, and we endeavour to provide them through our museum approach to informal but lifelong learning.

\section{Notes}

1. J. Dewey, Experience and Nature. Dover Publications, New York, 1958. Dewey stresses the importance of children's experiences in the outdoor environment.

2. Father Thomas Berry, 1914-2009. A cultural historian and Ecotheologian. Founder of the Thomas Berry Foundation, 1998. See Father T. Berry, The Dream of the Earth, Sierra Club Books, San Francisco, 1988. Father Berry discusses the interconnected nature of the planet and our place on it.

3. This type of authentic curriculum was advocated by Comenius many years ago. See J.A. Comenius, The School of Infancy (edited with an introduction by E.M. Elter), University of North Carolina Press, Chapel Hill, 1998.

4. S. Rowe \& S. Humphries, The Coombes Approach, Continuum (Bloomsbury). Publications London, 2012. Chapters 4 and 8 give more detailed descriptions of the Geology Trail.

5. Andy Goldsworthy: a British artist and sculptor whose ephemeral artwork with found objects in the natural environment has influenced our work at school.

6. Bruner emphasizes the need for dialogue between "the more experienced and the less experienced" in order to enhance learning. See J. Bruner, The Culture of Education, Harvard University Press, Cambridge, MA, 1996. 


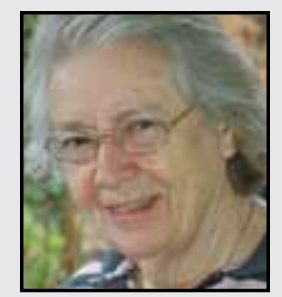

Susan Humphries was the founding headteacher of The Coombes School in Arborfield, Berkshire, UK and she led the school from its opening in 1971 until her retirement in 2002. She is a Trustee of the Learning Through Landscapes Trust and in 2011 was awarded an honorary Doctorate of the University of Agricultural Sciences in Uppsala, Sweden. She still works on a voluntary basis at the school.

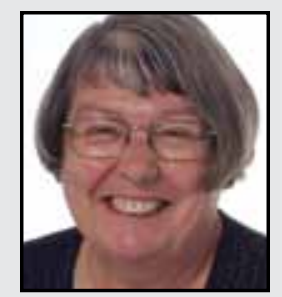

Susan Rowe worked at the school starting in 1978. She became deputy headteacher from 1991 and in 2003 became headteacher. She has also worked on a part-time basis as a Lecturer with the Open University, leading a one-year course that offers specialist training for classroom assistants and also with Reading University, teaching elements of a Foundation Degree for classroom assistants and pre-school leaders. She retired in 2010.

The authors have collaborated on a number of books and other publications and have recently completed a book describing the work, ethos, and development of The Coombes School. 